I HAVE been much interested in reading the above, and $I$ hope that Mr. Hay's example will be followed by other observers, in order to establish a fair average result of the relative cost of the coke-gas grate and the ordinary coal grate. Mr. Hay's results are not as favourable as those obtained by myself, owing probably to some imperfection in his arrangements, which are not described sufficiently to form any judgment upon them. I should like to know, for instance, whether the copper-back plate, which I presume he used, although it is not referred to, was backed by fireclay, or whether it touched the ironwork of the fireplace, whereby its heat would be conducted away. This alone might account for the difference in result obtained by Mr. Hay and myself, and I think this opportunity is a favourable one to send you the figures resulting from my own observation of the original grate described in my article in NATURE, vol. xxiii. p. 25. This grate has now been in use from November 8 to January $3 \mathrm{I}$, during which period it has been alight sixty-six days, and the average time during which a bright fire has been kept up has been eight hours daily. During this period of 528 hours there has been consumed-

$\begin{array}{llllllll}\text { III2 lbs. coke at } 18 s . \text { a ton } & \ldots & \ldots & \ldots & \ldots & 0 & 9 & 0 \\ 58 \mathrm{r} \text { lbs. smokeless coal at } 20 . . \text { a ton } & \ldots & \ldots & 0 & 5 & 2 \\ 4100 \text { cubic feet of grs at } 3 s .6 d . \text { per } 1000 & \ldots & 0 & 14 & 4 \\ & & & \text { I } & 8 & 6\end{array}$

Or an average of $0.518 d$. per hour, instead of $0.525 d$, as resulting from my first observation. The average consumption of solid fuel per hour has been $3.2 \mathrm{lbs}$, and of gas 7.7 cubic feet. The full supply of gas has generally been allowed during the first hour of lighting, after which it is turned down to about a third; this I find to be a convenient mode of working.

In comparing my results with Mr. Hay's, it must be borne in mind that my room has a capacity of 7200 cubic feet, with northern aspect, and his a capacity of 3000 cubic feet, also with northern aspect; his consumption should therefore be only $\frac{3000}{7200} \times 0.518=0.216 d$. (instead of $0.347 d$.), which figure would

prove an economy in the employment of the coke-gas grate over the coal grate, which is $0^{*} 2785 \mathrm{~d}$. by his own showing, and would agree with the comparative results contained in my original communication.

C. W. SIEMENS

February 2

\section{On the Spectrum of Carbon}

IT is very desirable that, if possible, some definite conclusion should be arrived at concerning the chemical origin of the bands, which Prof. Liveing calls "hydrocarbon bands," and the in. portance of the foint at issue must be my excuse for again addressing you on this subject.

In my previous communications I pointed out that if it can he shown experinentally that the electric spark, in an atmosphere of cyanogen fre from hy drogen, gives the groups in question (the grou $_{i} \delta$ and $\gamma$, wave-lengtbs 5165 to 5082 and 5635 to 5478 respectively, are here the only ones considered), they must be due to carbon, and remarked that the hypothesis that they were due to traces of hydrogen present as impurity is "to adopt an extreme hypothesis which must be supported by cogent experimental evidence before it can be accepted." Prof. Liveing admits the justice of this demand, and then goes on to say that such " cogent experimental evidence, so far as the relations of carbon and nitrogen are concerned, will be found in our complete papers on the spectrum of carbon compounds in the Proceedings of the Royal society." This appears to me to be equivalent to an admission that-as concerns carbon and hydrogen-no such experimental evidence has yet been given; which is also the conclusion to which I came after perual of the papers of Profs. Liveing and Dewar referred to.

It would seem then that the burden of proof that cyanogen exists in which the spark will not give rise to the bands $\delta$ and $\gamma$ rests with Prof. Liveing. Nevertheless I have repeated the experiment with cyanogen, described in this journal (vol. xxiii. p. 197), so as to set aside the objections raised by Prof. Liveing to the former experiment. The apparatus was in this case constructed of one piece of glass-a long piece of hard glass tubing. This was carefully cleaned, the tube was then contracted at two points, so as to separate a short portion of the tube, irto which platinum wires were fused, so as to form a discharge tube. The whole tube was next heated to rerl- ness in a furnace, while a current of oxyge: passed through it for some considerable time. The greater portion of the tube on each side of the part containing the wires was then filled with phosphoric anhydride, and a short length of the tube, separated from the discharge tube by as great a length of phosphoric anhyciride as the length of the tube permitted, was employed as a retort, and filled wirh mercuric cyanide; the other end of the tube was drawn out and dipped beneath sulphuric acid. The mercuric cyanide employed, after being finely powdered, was dried for a long time in an air-bath, then transferied to a clean bard-glass tube, in which it was repeatedly heated, while a current of air dried by passing over calcium-chloride and phosphoric anlyydride was drawn over it. From this tube it was transferred immediately to the retort-tulue. In luaking the experiment the mercuric cyanide was heated $: 0$ as to give as slow a current of cyanogen as possible, which was continued long enongh to expel all the air from the tube. The tulye was then sealed up, leaving the discharie-tube, with a phoshoric anhydride tube on each side of it, and put aside for a week. 'The spectrum was then examined, with the same result as before. The tube gave a brilliant carbon spectrum, of which $\gamma$ and $\delta$ (the positions of which were measuredi) were the brightest groups. No tracc of the hydrogen $\mathrm{C}$-line was obtained. Prof. Liveing objects that this is not a sufficient proof that liydrogen is absent (in which I cannot agree with him), and saggests that "a real test would be to set whether, when the sirark gives the linespectrum of carbon, the hydrogen-lines do not also appear." This test is however not applicable, since (according to my experience) cyanogen cannot be made to give the line-spectrum of carbon. Further, in this particular case the spark could not be got through the tube when the condenser was put on. Giggleswick, February ir

W. M. WatTs

\section{"Prehistoric Europe"}

As there was no space to allow of all the authrilies being cited in my criticism of the above work I now give those which relate to the facts called in question by Dr. James Geilie in NATURE, vol. xxiii. p. 336 .

I. Dr. James Geikie repudiates as absurd the view attributed to him, that the palæolithic gravels "which overlie the chalky bouider clay of East Anglia were covered by an upper and younger boulder clay," and denies that he ever wrote anything which wonld justify that opinion. In "The Great Ice Age," 2nd edition, p. 53r, he writes: "The palæolithic beds dovetail into the glacial drifts, and are overlapped (as in Yorkshire) by the deposits thrown down during the final cold pericd. To the last interglacial period then we must refer the great bulk of the palaolithic river gravels of the scuth-east of England." If this be true, where are the glacial deposits in question to be seen? If the ever were alove, or "overlapped," the jalæolithic gravels, they have, :o far as our present kiowledge goes, been utterly destroyed. Of course this view is absurd.

2. The reindeer associated " ith the hippopotamus and hyæna in the same stratum in the Victoria Cave was discovered while the exploration was under my management, and was published in Brit. Assoc. Rep. 1872, Trans. p. I79, and again in Mr. Tiddeman's Report, op. cit. 1876, Reports, p. I18. The animal is omitted by the author where its presence would destroy his argument as to climate, but he does not forget to record its subsequent dis. covery at a higher level, where it falls in with his argument. It may be remarked that the association of rindeer with hippo. potamus in this cave has no sfecial theorcitcal value, tecause the two animals have been found together in several other hyæna dens.

3. The fossil mammalia of Mont Perrier are typical Uprer Pleiocene, as may be seen from the works of Croizet and jobert, Gaudry and Gervais, and as I can testify from their examination. The glacial origin of the overlying tuffs, which I have examined under the guidance of M. Julien, seems to me to be open to considera! le doubt.

4. The mammalia of Leffé, and those of the Val d'Arno with which they are classified by Dr. James Geikie, characterise the Upper Pleiocenes of Italy, as may be seen from the careful essays publisbed by Dr. Forsyth Major, and from an exavination of the magnificent collection in the museum of the University of Florence.

5. If payes 309-318 of "Prehistoric Europe," dealing with " interglacial epochs," do not imply a belief that the Neolithic skull of Olmo is interglacial, I am unable to ascertain their meaning. 